\title{
Exploring DRD4 and Its Interaction With SLC6A3 as Possible Risk Factors for Adult ADHD: A Meta-Analysis in Four European Populations
} Cristina Sánchez-Mora, ${ }^{1,2,3}$ Marta Ribasés, ${ }^{1,2}$ Miquel Casas, ${ }^{1,4}$ Mònica Bayés, ${ }^{5}$ Rosa Bosch,, ${ }^{1,4}$
Noelia Fernàndez-Castillo, ${ }^{3,6}$ Lucas Brunso, ${ }^{3}$ Kaya K. Jacobsen, ${ }^{7,8}$ Elisabeth T. Landaas, Astri J. Lundervold, ${ }^{9}$ Silke Gross-Lesch, ${ }^{10}$ Susanne Kreiker, ${ }^{11}$ Christian P. Jacob, ${ }^{10}$ Klaus-Peter Lesch, ${ }^{10}$ Jan K. Buitelaar, ${ }^{12}$ Martine Hoogman, ${ }^{13}$ Lambertus A.L.M. Kiemeney, ${ }^{14}$ J.J. Sandra Kooij, ${ }^{15}$ Eric Mick, ${ }^{16}$ Phil Asherson, ${ }^{17}$ Stephen V. Faraone, ${ }^{18}$ Barbara Franke, ${ }^{13,19}$ Andreas Reif, ${ }^{10}$ Stefan Johansson, ${ }^{7,8}$ Jan Haavik, ${ }^{8,20}$ Josep Antoni Ramos-Quiroga, ${ }^{1,4}$ and Bru Cormand ${ }^{3,6,21 *}$

${ }^{1}$ Department of Psychiatry, Hospital Universitari Vall d'Hebron, Barcelona, Catalonia, Spain

${ }^{2}$ Psychiatric Genetics Unit, Hospital Universitari Vall d'Hebron, Barcelona, Catalonia, Spain

${ }^{3}$ Facultat de Biologia, Departament de Genètica, Universitat de Barcelona, Catalonia, Spain

${ }^{4}$ Department of Psychiatry and Legal Medicine, Universitat Autònoma de Barcelona, Catalonia, Spain

${ }^{5}$ Centro Nacional de Análisis Genómico (CNAG), Parc Científic de Barcelona (PCB), Catalonia, Spain

${ }^{6}$ CIBER Enfermedades Raras, Barcelona, Catalonia, Spain

?Department of Medical Genetics and Molecular Medicine, Haukeland University Hospital, Bergen, Norway

${ }^{8}$ Department of Biomedicine, University of Bergen, Bergen, Norway

${ }^{9}$ Department of Biological and Medical Psychology, University of Bergen, Bergen, Norway

${ }^{10}$ Department of Psychiatry, Psychosomatics and Psychotherapy, University of Würzburg, Würzburg, Germany

${ }^{11}$ Department of Child and Adolescent Psychiatry and Psychotherapy, University of Würzburg, Würzburg, Germany

${ }^{12}$ Department of Cognitive Neuroscience, Donders Institute for Brain, Cognition and Behavior, Radboud University Nijmegen Medical Centre, Nijmegen, The Netherlands

${ }^{13}$ Department of Psychiatry, Donders Institute for Brain, Cognition and Behavior, Radboud University Nijmegen Medical Centre, Nijmegen, The Netherlands

${ }^{14}$ Department of Epidemiology, Biostatistics and HTA, Radboud University Nijmegen Medical Centre, Nijmegen, The Netherlands

Additional Supporting Information may be found in the online version of this article.

Grant sponsor: “Instituto de Salud Carlos III-FIS," Spain; Grant numbers: PI040524 PI041267, PI080519; Grant sponsor: “Fundació La Marató de TV3"; Grant number: 092330/31; Grant sponsor: “Agència de Gestió d’Ajuts Univeristaris i de Recerca-AGAUR”; Grant number: 2009SGR-00971; Grant sponsor: Obra Social - Fundació "La Caixa”; Grant number: 2007-2010; Grant sponsor: Subdirecció General de Drogodependències, Departament de Salut, and Pla Director de Salut Mental i Addiccions, Catalonia Government (Generalitat de Catalunya); Grant sponsor: Hersenstichting Nederland (Fonds Psychische Gezondheid); Grant sponsor: Research Council of Norway; Grant sponsor: Western Norway Regional Health Authority; Grant sponsor: The National Research Network for ADHD; Grant sponsor: The University of Bergen; Grant sponsor: DFG; Grant numbers: RE1632/1-5, KFO 125 SFB TRR 58/A1,5, Z02, GRK 1156; Grant sponsor: GK Emotions; Grant sponsor: BMBF; Grant number: 01GV0605; Grant sponsor: EC; Grant number: NEWMOOD LSHM-CT-2003-503474.

Conflict of interest: Netherlands: In the past 3 years, Jan K. Buitelaar has been a consultant to/member of advisory board of and/or speaker for Janssen Cilag BV, Eli Lilly, Bristol-Myer Squibb, Organon/Shering Plough, UCB, Shire, Medice, and Servier. He is not an employee of any of these companies. He is not a stock shareholder of any of these companies. He has no other financial or material support, including expert testimony, patents or royalties. Sandra Kooij has received research grants from Janssen BV en Shire, and is on the speaker's bureau of Janssen and Eli Lilly. Martine Hoogman, Lambertus Kiemeney, and Barbara Franke declare no conflicts of interest. Norway: Jan Haavik has been a consultant for Janssen Cilag and Novartis. Authors from Germany and Spain declare no conflicts of interest.

Barbara Franke, Andreas Reif, Stefan Johansson, Jan Haavik, Josep Antoni Ramos-Quiroga, and Bru Cormand contributed equally to this study. ${ }^{\star}$ Correspondence to:

Dr. Bru Cormand, Associate Professor of Genetics, Facultat de Biologia, Departament de Genètica, Universitat de Barcelona, Av. Diagonal 645, Edifici Annex, 3- Planta, 08028 Barcelona, Spain. E-mail: bcormand@ub.edu

Published online 18 May 2011 in Wiley Online Library

(wileyonlinelibrary.com).

DOI 10.1002/ajmg.b.31202 


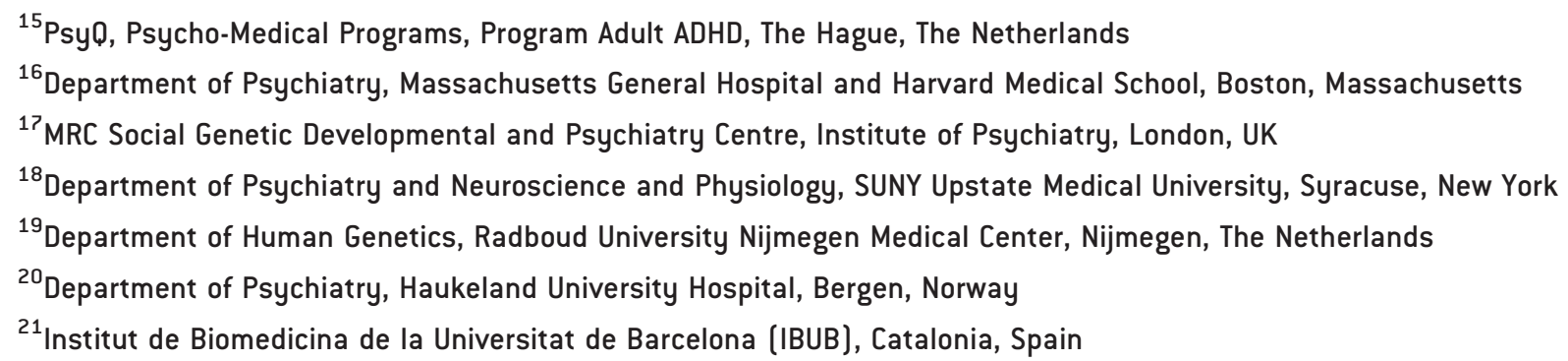

Received 24 November 2010; Accepted 25 April 2011

Attention-deficit hyperactivity disorder (ADHD) is a common behavioral disorder affecting about $4-8 \%$ of children. ADHD persists into adulthood in around $65 \%$ of cases, either as the full condition or in partial remission with persistence of symptoms. Pharmacological, animal and molecular genetic studies support a role for genes of the dopaminergic system in ADHD due to its essential role in motor control, cognition, emotion, and reward. Based on these data, we analyzed two functional polymorphisms within the $D R D 4$ gene $(120 \mathrm{bp}$ duplication in the promoter and 48 bp VNTR in exon 3 ) in a clinical sample of 1,608 adult ADHD patients and 2,352 controls of Caucasian origin from four European countries that had been recruited in the context of the International Multicentre persistent ADHD CollaboraTion (IMpACT). Single-marker analysis of the two polymorphisms did not reveal association with ADHD. In contrast, multiplemarker meta-analysis showed a nominal association $(P=0.02)$ of the L-4R haplotype (dup120bp-48bpVNTR) with adulthood ADHD, especially with the combined clinical subtype. Since we previously described association between adulthood ADHD and the dopamine transporter SLC6A3 9R-6R haplotype (3'UTR VNTR-intron 8 VNTR) in the same dataset, we further tested for gene $\times$ gene interaction between $D R D 4$ and SLC6A3. However, we detected no epistatic effects but our results rather suggest additive effects of the DRD4 risk haplotype and the SLC6A3 gene. () 2011 Wiley-Liss, Inc.

Key words: attention-deficit hyperactivity disorder; casecontrol association study; neurotransmission; dopamine; psychiatric genetics

\section{INTRODUCTION}

Attention-deficit hyperactivity disorder (ADHD) is a common behavioral disorder affecting $4-8 \%$ of children [Polanczyk et al., 2007] and is characterized by inappropriate and impairing levels of hyperactivity, impulsivity, and inattention. ADHD persists into adulthood in around 65\% of cases either as the full condition or in partial remission with persistence of symptoms and with significant clinical impairment [Faraone et al., 2006; Lara et al., 2009]. A review of 20 twin studies in children estimated the heritability of ADHD to be around 76\% [Faraone et al., 2005; Faraone and Mick, 2010].

Pharmacological studies, animal models, and molecular genetic studies support a role for genes of the dopamine, serotonin, and norepinephrine neurotransmitter systems in ADHD. Research, however, has mainly focused on the dopaminergic system due to

\section{How to Cite this Article:}

Sánchez-Mora C, Ribasés M, Casas M, Bayés M, Bosch R, Fernàndez-Castillo N, Brunso L, Jacobsen KK, Landaas ET, Lundervold AJ, Gross-Lesch S, Kreiker S, Jacob CP, Lesch KP, Buitelaar JK, Hoogman M, Kiemeney LALM, Kooij JJS, Mick E, Asherson P, Faraone SV, Franke B, Reif A, Johansson S, Haavik J, Ramos-Quiroga JA, Cormand B. 2011. Exploring DRD4 and its interaction with $S L C 6 A 3$ as possible risk factors for adult ADHD: A meta-analysis in four European populations.

Am J Med Genet Part B 156:600-612.

its essential role in motor control, cognition, and reward. In this regard, magnetic resonance imaging suggests abnormalities in ADHD-affected children in neuro-anatomical areas rich in dopaminergic innervations [Ernst et al., 1999; Durston et al., 2005]. In addition, methylphenidate, amphetamine, and other psychostimulant drugs increase synaptic levels of dopamine and are effective in the control of ADHD symptoms through blockade of the dopamine transporter.

Among the different genes involved in dopaminergic neurotransmission, the dopamine receptor D4 (DRD4) has been widely considered in genetic studies of ADHD. The DRD4 gene is located at chromosome $11 \mathrm{p} 15.5$, organized in 4 exons and encodes a G-protein-coupled receptor belonging to the dopamine D2-like receptor family. This family of receptors is expressed predominantly in the prefrontal cortex. DRD4 contains a number of polymorphisms, one of which, a variable number of $48 \mathrm{bp}$ tandem repeats (48bpNTR), is located in the third exon of the gene. This exon encodes the putative third cytoplasmic loop of the receptor and modulates the receptor's signal transduction properties by altering intracellular cyclic AMP levels [Van Tol et al., 1992]. This polymorphism, with a unit that is repeated from $2(2 \mathrm{R})$ to $11(11 \mathrm{R})$ times, shows considerable inter-ethnic heterogeneity [Van Tol et al., 1992; Chang et al., 1996]. Although its effect on the DRD4 function is still unknown, different pharmacological properties have been described for the distinct repeat lengths, with the 7R allele dampening the response of cells to dopamine [Asghari et al., 1995]. Other studies, however, showed no evidence of quantitative 
differences in G-protein coupling among the DRD42R, 4R, and 7R alleles [Kazmi et al., 2000].

Since the publication of the initial study by LaHoste et al. [1996] showing association between the 7R allele of the 48bpVNTR and ADHD in children, many case-control and family-based association studies have been reported, although they show controversial results. After the first studies that identified the $7 \mathrm{R}$ as a risk allele for ADHD, most of the subsequent work solely tested this allele versus all the others [Castellanos et al., 1998; Comings et al., 1999; Muglia et al., 2000; Tahir et al., 2000; Curran et al., 2001; Mill et al., 2001; Langley et al., 2004; Gabriela et al., 2009]. Other studies differentiated between short $(2 \mathrm{R}-5 \mathrm{R})$ and long alleles $(6 \mathrm{R}-11 \mathrm{R})$ [Eisenberg et al., 2000; Hawi et al., 2000; Kotler et al., 2000; Manor et al., 2002]. However, only some of these studies focused on adult ADHD [Muglia et al., 2000; Smith et al., 2003; Johansson et al., 2008]. Johansson et al. [2008] found no association between the DRD4 VNTR polymorphism and adulthood ADHD. On the other hand, Muglia et al. [2000] suggested a role of the 7R allele in adult ADHD and, finally, although performed in childhood ADHD samples, several meta-analyses have demonstrated a significant association between this DRD4 allele and ADHD [Faraone et al., 2001; Faraone et al., 2005; Li et al., 2006; Gizer et al., 2009; Nikolaidis and Gray, 2010; Smith, 2010]. However, some of these meta-analyses detected significant heterogeneity in the effect size for DRD4 in the different studies [Li et al., 2006; Gizer et al., 2009; Smith, 2010].

Seaman et al. [1999] subsequently identified a second common genetic variant in DRD4, the $120 \mathrm{bp}$ duplication (dup120bp) located $1.2 \mathrm{~kb}$ upstream of the DRD4 translation initiation codon. The duplication contains consensus sequences for several transcription factors and modulates transcription of the DRD4 gene. In this regard, the $240 \mathrm{bp}$ allele (long or L allele) showed enhanced binding capacity for the Sp 1 transcription factor in a mobility shift assay and exhibited lower transcriptional activity than the $120 \mathrm{bp}$ allele (short or S allele) in transfected cell lines [D'Souza et al., 2004; Ronai et al., 2004; Kereszturi et al., 2007]. Several studies have tested association between the DRD4 dup120bp polymorphism and ADHD but results are also controversial, showing no association [Barr et al., 2001; Todd et al., 2001; Brookes et al., 2005; Bhaduri et al., 2006; Gizer et al., 2009] or identifying either the L or S alleles as risk factors for ADHD [McCracken et al., 2000; Kustanovich et al., 2004; Kereszturi et al., 2007]. Accordingly, a recent meta-analysis performed by Gizer et al. [2009] found no association between childhood ADHD and either allele. So far, Arcos-Burgos et al. [2004] were the only researchers to study the role of a haplotype of both polymorphisms in ADHD and indeed found significant evidence for association with the S-7R DRD4 haplotype.

Since both the 48b VNTR and the dup120bp polymorphisms in $D R D 4$ may affect the receptor function through changes in amino acid sequence or promoter activity and to challenge the inconsistencies raised among previous case-control and family-based association studies, we aimed to investigate the possible involvement of these polymorphisms in ADHD in a large sample of adult patients and controls from Europe. We performed a meta-analysis of unpublished case-control data from four different countries (Germany, The Netherlands, Norway, and Spain) integrated in the International Multicentre persistent ADHD CollaboraTion (IMpACT) in a sample of 1,608 adult ADHD patients and 2,352 controls. Also, as several studies have shown epistatic [Roman et al., 2001; Gabriela et al., 2009] or additive effects [Carrasco et al., 2006] between DRD4 and SLC6A3 in ADHD or hyperactive-impulsive symptoms [Auerbach et al., 2010], we used previously published SLC6A3 genotype data from IMpACT [Franke et al., 2010] to assess their potential combined contribution to adulthood ADHD.

\section{MATERIALS AND METHODS}

\section{Patients and Controls}

In total, 1,608 adult ADHD patients and 2,352 controls of Caucasian origin from four European countries (Spain, Germany, Norway, and The Netherlands) were recruited at four sites of IMpACT. Table I shows the clinical description of these patient cohorts. Diagnosis was blind to genotype. The study was approved by the ethics committee of each participating institution and informed consent was obtained from all subjects in accordance with the Helsinki Declaration.

Consensus eligibility criteria for the current study across all sites were a diagnosis of ADHD according to the diagnostic criteria of Diagnostic and Statistical Manual for Mental Disorders-IV (DSM-IV), onset before the age of 7 years via retrospective diagnosis (which was confirmed by a family member, wherever possible), lifelong persistence, and current diagnosis. Patients were extensively examined by psychiatrists experienced in adult ADHD and were evaluated for other psychiatric disorders with the Structured Clinical Interview of DSM-IV for axis-I (and axis-II) disorders (SCID-I, SCID-II) or semi-structured interviews. Most controls (except for the Norwegian samples and part of the German samples) were screened for the presence of ADHD and those scoring high on symptoms of the disorder were excluded (for a more detailed description of the different diagnostic instruments, see Sanchez-Mora et al., 2010).

\section{DNA Isolation and Genotyping}

Genomic DNA was isolated either from saliva using the Oragene DNA Self-Collection Kit (DNA Genotek Inc., Ottawa, Ontario, Canada) or from peripheral blood lymphocytes by the salting-out procedure [Miller et al., 1988].

Dup120bp DRD4 polymorphism. Genotyping was carried out using standard PCR methods and amplification products were tested by electrophoresis on a $1.5 \%$ agarose gel and ethidium bromide staining (Germany, Spain, and The Netherlands) or visualized on an $\mathrm{ABI} 3100$ sequencer and automatically called using the GeneMapper software (Applied Biosystems, Foster City, CA). Genomic DNA was amplified with primers $5^{\prime}$-GTTGTCTGTCTTTTCTCATTGTTTCCATTG-3' ${ }^{\prime}$ and $5^{\prime}$-GAAGGAGCAGGCACCGTGAGC- $3^{\prime}$ for the Spanish, German, and Dutch samples and with a fluorescently labeled (FAM) reverse primer for the Norwegian samples. For the German, Spanish, and Norwegian samples, PCR reactions were carried out in a final volume of $10 \mu \mathrm{l}$, l, containing $5 \mathrm{ng}$ of genomic DNA, $0.5 \mathrm{pmol}$ of each primer, $1 \mu \mathrm{l}$ PCRx Enhancer solution $(10 \times$; PCRx Enhancer System, Invitrogen, Breda, The Netherlands), $1 \mu$ l PCRx Amplification Buffer (PCRx Enhancer System, Invitrogen), $0.2 \mu \mathrm{M}$ of each dNTP, $0.5 \mathrm{mM}$ $\mathrm{MgSO}_{4}$, and $1 \mathrm{U}$ of Taq polymerase. Amplification conditions 
TABLE I. Descriptive Characteristics of the IMpACT Samples From Four European Countries

\begin{tabular}{|c|c|c|c|c|c|c|c|c|}
\hline & Germany & Netherlands & Norway & Spain & Pool & $\begin{array}{c}\text { DRD4 } \\
\text { Dup120bp }\end{array}$ & $\begin{array}{c}\text { DRD4 } \\
\text { 48bpVNTR }\end{array}$ & $\begin{array}{c}\text { DRD4 } \\
\text { Dup120bp- } \\
\text { 48bpVNTR }\end{array}$ \\
\hline \multicolumn{9}{|l|}{ Controls } \\
\hline Female & 307 [53.6) & 248 (50.7) & $325(55.6)$ & $245(34.8)$ & 1,125 (47.8) & 872 (42.3) & 813 (44.2) & 845 (46.0) \\
\hline Male & $266(46.4)$ & 241 (49.3) & $260[44.4]$ & $460(65.2)$ & $1,227[52.2]$ & 1,190 [57.7] & $1,027(55.8)$ & $990(54.0)$ \\
\hline Total & $573(24.36)$ & 489 (20.79) & 585 [24.87] & 705 (29.97) & 2,352 & 2,062 & 1,840 & 1,835 \\
\hline Age (mean and SD) & 30.73 (9.8) & 63.46 (18.07) & $27.4(7.16)^{a}$ & 45.26 (14.79) & & & & \\
\hline \multicolumn{9}{|l|}{ Cases } \\
\hline Female & $304(48.8)$ & $119(50.0)$ & $215(47.4)$ & $82(28.0)$ & $720(44.8)$ & $644(44.5)$ & $613(43.6)$ & $537(43.2)$ \\
\hline Male & 319 [51.2] & 119 (50.0) & $239[52.6]$ & 211 (72.0) & 888 [55.2] & $803(55.5)$ & $794(56.4)$ & 709 (56.8) \\
\hline Total & 623 (38.7) & 238 (14.8) & 454 (28.2) & 293 [18.22] & 1,608 & 1,447 & 1,407 & 1,246 \\
\hline Age (mean and SD) & $33.91(10.12)$ & $41.23(11.35)$ & 33.9 (11.6) & $36.02(16.83)$ & & & & \\
\hline \multicolumn{9}{|l|}{ ADHD subtype } \\
\hline Combined type & $422(68.3)$ & $202(86.0)$ & 327 (72.03) & $194(66.2)$ & 1,145 (71.2) & 1,037 (71.7) & $991(70.4)$ & $883(71.0)$ \\
\hline Inattentive type & $151(24.4)$ & $24[10.2]$ & 47 (10.35) & 87 (29.7] & 309 [19.2] & 279 (19.3) & 275 (19.5) & 243 (19.5) \\
\hline Hyperactive/impulsive type & 45 (7.3) & 9 [3.8] & $15(3.30)$ & $12[4.1]$ & $81(5.04)$ & $67[4.6]$ & $72(5.1)$ & 58 (4.7) \\
\hline Sub-threshold & - & - & 45 (9.91) & - & $45(2.8)$ & 44 (3.0) & $45(3.2)$ & $44(3.5)$ \\
\hline Unknown & - & - & $20(4.41)$ & - & $20(1.2)$ & $20(1.38)$ & $20(1.42)$ & $16(1.04)$ \\
\hline
\end{tabular}

consisted of an initial denaturation at $94^{\circ} \mathrm{C}$ for $1 \mathrm{~min}$ followed by 34 cycles of denaturation at $94^{\circ} \mathrm{C}$ for $1 \mathrm{~min}$, annealing at $56.5^{\circ} \mathrm{C}$ for $1 \mathrm{~min}$, and extension at $72^{\circ} \mathrm{C}$ for $1 \mathrm{~min}$, with a final extension step at $72^{\circ} \mathrm{c}$ for $10 \mathrm{~min}$. The amplification yielded distinct bands at $429 \mathrm{bp}$ (short "S" allele) and 549 bp (long "L" allele). For Dutch samples, genotyping of the $120 \mathrm{bp}$ tandem duplication polymorphism was carried out using a PCR-based method as described by Seaman et al. [1999]. PCR was performed on $62.5 \mathrm{ng}$ genomic DNA using $0.4 \mu \mathrm{M}$ of each of the primers described above, $0.25 \mathrm{mM}$ dNTPs, $0.5 \mathrm{U}$ Taq DNA polymerase (Invitrogen) in a PCR buffer containing $10 \mathrm{mM}$ Tris-HCl pH 8.0, $50 \mathrm{mM} \mathrm{KCl,} \mathrm{0.1 \%} \mathrm{Triton} \mathrm{X-100} \mathrm{(v/v),} \mathrm{0.015 \%}$ gelatin $(\mathrm{w} / \mathrm{v}), 5 \%$ DMSO $(\mathrm{v} / \mathrm{v})$, and $1.5 \mathrm{mM} \mathrm{MgCl}_{2}$. The cycling conditions were $10 \mathrm{~min} 92^{\circ} \mathrm{C}$ followed by 35 cycles of $1 \mathrm{~min} 95^{\circ} \mathrm{C}$, $1 \min 58^{\circ} \mathrm{C}, 1 \min 72^{\circ} \mathrm{C}$. At the end of the protocol, $10 \mathrm{~min}$ at $72^{\circ} \mathrm{C}$ were added.

$48 \mathrm{bp}$ VNTR DRD4 polymorphism. Genotyping of the DRD4 $48 \mathrm{bp}$ VNTR polymorphism in exon 3 was performed according to the method used by Johansson et al. [2008] for samples from Norway and Spain. A protocol for PCR amplification and fragment analysis is available upon request. In short, DNA was amplified with the following primers: $5^{\prime}$-CGTACTGTGCGGCCTCAACGA-3' and FAM-5'-GACACAGCGCCTGCGTGATGT- $3^{\prime}$. The reverse primer was fluorescently labeled and PCR products were visualized on an ABI 3100 sequencer and automatically called using the GeneMapper software (Applied Biosystems). All genotype calls were also manually inspected. Analysis of the results using Genemapper showed fragment length at $598 \mathrm{bp}$ (2 repeats), $646 \mathrm{bp}$ (3 repeats), $694 \mathrm{bp}$ (4 repeats), $742 \mathrm{bp}$ (5 repeats), $790 \mathrm{bp}$ (6 repeats), $836 \mathrm{bp}$ (7 repeats), $884 \mathrm{bp}$ (8 repeats), $930 \mathrm{bp}$ (9 repeats), and $976 \mathrm{bp}$ (10 repeats).

For the Dutch sample, the $48 \mathrm{bp}$ repeat polymorphism was analyzed by simple sequence analysis on a genetic analyzer using primers as described earlier [Lichter et al., 1993]. For the PCR amplification, $50 \mathrm{ng}$ of genomic DNA, $1.25 \mu \mathrm{M}$ fluorescent labeled forward primer (5'-Vic-GCGACTACGTGGTCTACTCG-3') and $1.25 \mu \mathrm{M}$ reverse primer with PIG tail (5'-AGGACCCTCATGGCCTTG-3'), $0.4 \mathrm{mM}$ dNTPs, $1 \times$ GCI Buffer TaKaRa (Lucron Bioproducts BV, Gennep, The Netherlands), 0.5 U TaKaRa LA Taq ${ }^{\mathrm{TM}}$ (Lucron Bioproducts BV), and $1 \mathrm{M}$ betaine were used. The cycling conditions were $1 \mathrm{~min} 94^{\circ} \mathrm{C}$ followed by 35 cycles of $30 \mathrm{sec} 94^{\circ} \mathrm{C}, 30 \sec 58^{\circ} \mathrm{C}, 1 \mathrm{~min} 72^{\circ} \mathrm{C}$, with a final $5 \mathrm{~min}$ step at $72^{\circ} \mathrm{C}$. The PCR product was diluted 10 times and $1 \mu \mathrm{l}$ of the diluted PCR product together with $9.7 \mu \mathrm{l}$ formamide and $0.3 \mu \mathrm{l} \mathrm{GeneScan-}$ 600 Liz Size StandaardTM (Applied Biosystems, Nieuwerkerk aan de IJssel, The Netherlands) was analyzed on a 3730 Genetic Analyzer according to the protocol of the manufacturer. Analysis of the results using Genemapper showed fragment length at $378 \mathrm{bp}$ (2 repeats), $426 \mathrm{bp}$ (3 repeats), $474 \mathrm{bp}$ (4 repeats), $522 \mathrm{bp}$ (5 repeats), $570 \mathrm{bp}$ (6 repeats), $618 \mathrm{bp}$ (7 repeats), and $666 \mathrm{bp}$ (8 repeats).

For the German sample, PCR amplification was performed using Vent polymerase (New England Biolabs, Ipswich, MA) and a high denaturing temperature $\left(98^{\circ} \mathrm{C}\right.$ for $\left.1 \mathrm{~min}\right)$ with a combined annealing and extension reaction for $5 \mathrm{~min}$ at $70^{\circ} \mathrm{C}$. The primers were $5^{\prime}$ GCGACTACGTGGTCTACTCG-3' and 5'AGGACCCTCATGGCCTTG-3'. Thirty PCR cycles were performed and subsequently, the reaction mixture was electrophoresed on a $2 \%$ Metaphor gel (FMC) with ethidium bromide. The lengths of the resulting PCR products are the same as describe above for the Dutch sample.

\section{Statistical Analysis}

Separate analysis of the four European samples. We first performed a single- and multiple-marker analysis on the samples 
from the four IMpACT sites, separately, and then analyzed the pooled sample using a meta-analytical approach. Hardy-Weinberg equilibrium (HWE) in the control groups from each IMpACT node as well as in the whole control sample was assessed using a chi-squared test with the HWE software v.1.05 (www.linkage.rockefeller.edu/soft/linkutil). Genotype and allele frequencies of the dup120bp and 48bpVNTR polymorphisms were compared between cases and controls from each separate IMpACT site using a chi-squared test with the SNPassoc R package and the statistical package SPSS 15.0, respectively [Gonzalez et al., 2007]. Since the $48 \mathrm{bpVNTR}$ polymorphism is multiallelic $(2 \mathrm{R}-11 \mathrm{R}$ alleles), rare [minor allele frequency $(\mathrm{MAF})<5 \%$ ] genotypes and alleles were grouped in a single class as "others." Haplotype frequencies were estimated using the PHASE software [Stephens et al., 2001] and values below 5\% were grouped as "others" in the association analysis.

Meta-analysis. To combine the individual results, we conducted a meta-analysis using the Meta $\mathrm{R}$ package (www.cran.rproject.org/web/packages/meta/index.html). The analysis of the minimal statistical power was performed post hoc using the Genetic Power Calculator software (www.pngu.mgh.harvard. edu/ purcell/gpc), assuming a dominant model, an odds ratio (OR) of 1.5, prevalence of 0.05 , significance level of 0.05 and a MAF of 0.158 [Purcell et al., 2003]. We first tested heterogeneity among studies using the Q-statistic [Lau et al., 1997; Zintzaras and Hadjigeorgiou, 2004]. When no heterogeneity was present, the pooled OR was estimated using a fixed-effects model [Mantel and Haenszel, 1959]. A random-effect model was considered in those cases where heterogeneity was detected [Laird and Mosteller, 1990]. Meta-analysis was performed considering the whole ADHD sample, but also split by gender or ADHD clinical subtypes. The hyperactive-impulsive clinical sample could not be evaluated due to insufficient sample size.

For the dup120bp polymorphism, we determined the best genetic model to be used by estimating the three possible ORs and their $95 \%$ confidence intervals (CI) in the meta-analysis sample: OR1 (SS vs. $\mathrm{LL}$ ), OR2 (SS vs. LS), and OR3 (LS vs. LL). If OR $1=\mathrm{OR} 3 \neq 1$ and $\mathrm{OR} 2=1$, then a recessive model is suggested; $\mathrm{OR} 1=\mathrm{OR} 2 \neq 1$ and $\mathrm{OR} 3=1$ indicates a dominant model and $\mathrm{OR} 1>\mathrm{OR} 3>1$ (or OR $1<$ OR2 $<1$ and OR1 $<$ OR3 $<1$ ) suggests a codominant model. When none of the OR values significantly deviated from 1 , then meta-analyses were performed for the three different genetic models.

For the $48 \mathrm{bpVNTR}$ we minimized multiple-testing by restricting the meta-analysis to alleles or genotypes showing frequency differences $>3 \%$ among cases and controls in at least one of the study populations. Thus, alleles $4 \mathrm{R}$ and $7 \mathrm{R}$, and genotypes $4 \mathrm{R} 4 \mathrm{R}, 4 \mathrm{R} 7 \mathrm{R}$, and 7R7R were considered for meta-analysis. For the analysis of the dup $120 \mathrm{bp} / 48 \mathrm{bpVNTR}$ haplotype we only considered the carriers of the three major allelic combinations, S-4R, L-4R, and L-7R. The EH software was used to test the presence of linkage disequilibrium between the two DRD4 polymorphisms [Terwilliger and Ott, 1994].

DRD4 $\times$ SLC6A3 interaction analysis. A logistic regression analysis was used to evaluate the independent and interactive effects of the DRD4 and SLC6A3 loci. For DRD4 we considered the haplotype made up of the dup $120 \mathrm{bp} \mathrm{L}$ allele and the $4 \mathrm{R}$ allele of the $48 \mathrm{bpVNTR}$ polymorphism (L-4R), while for the SLC6A3 gene we considered the previously described risk haplotype comprising the 9R allele of the VNTR in the $3^{\prime} \mathrm{UTR}$ and the $6 \mathrm{R}$ allele of the VNTR in intron 8 (9R-6R), using pre-existing genotype data on our multicenter cohort of patients and controls [Franke et al., 2010]. A stepwise logistic regression procedure was implemented to compare two different regression models by a likelihood ratio test using the statistical package SPSS 15.0. In the first model, we considered the affection status as a dependent variable and the DRD4 and SLC6A3 haplotypes as predictive variables. In the second model, we included the interaction $D R D 4 \times S L C 6 A 3$ as an independent variable.

\section{RESULTS}

A total of 1,608 adult ADHD patients and 2,352 controls from four IMpACT sites were genotyped for the DRD4 dup120bp and/or the 48bpVNTR polymorphisms. The clinical description of the samples included in the study is shown in Table I.

\section{Single-Marker Analysis}

For the DRD4 dup120bp polymorphism, genotypes from 1,447 patients (90\%) and 2,062 controls (88\%) were available for the single-marker analysis. No significant departure from HWE was observed, neither in the control group from each population nor in the pooled sample $(P>0.05)$. No significant association was detected when we compared genotype and allele frequencies between cases and controls from each separate site (Supplementary Table SI). Stratification of the ADHD samples according to gender or clinical subtype in the four separate populations resulted in a nominal association between the L allele of the dup120bp polymorphism and ADHD in males from Norway $[P=0.009$, $\mathrm{OR}=1.69$ (1.14-2.56); Supplementary Table SII]. Nominal association was also observed in two samples when we considered the combined clinical subtype (Supplementary Table SIII): Norway $[P=0.04, \mathrm{OR}=1.40(1.01-1.96)]$ and Spain $[P=0.04, \mathrm{OR}=2.63$ (0.91-7.69)]. The evaluation of the best genetic model for the metaanalysis showed that none of the three ORs in the pooled sample significantly deviated from $1\left[\mathrm{OR} 1_{(\mathrm{SS}}\right.$ vs. $\left.\mathrm{LL}\right)=1.23(95 \% \mathrm{CI}$ : $0.82-1.84), \mathrm{OR} 2_{(\mathrm{SS} \text { vs. } \mathrm{LS})}=1.23(0.81-1.86)$, and $\mathrm{OR} 3_{(\mathrm{LS}}$ vs. LL) $=$ 1.03 (95\% CI: 0.88-1.20)] and, thus, we performed meta-analysis considering the dominant, recessive, and codominant models. However, no significant association was found for dup120bp in the full ADHD sample (Table II), or when patients were subdivided by gender or clinical subtypes, in either of the three models (data not shown).

A total of 1,407 patients (87.5\%) and 1,840 controls (78.2\%) had genotypes available for the DRD4 48bpVNTR polymorphism. Genotype frequencies did not deviate significantly from HWE in any of the cohorts $(P>0.05)$. No significant association between the 48bpVNTR and ADHD was identified in any of the European samples, when studied separately (Supplementary Table SIV). As described above (Materials and Methods Section), only 4R/4R, 4R/ $7 \mathrm{R}$, and 7R/7R genotypes were available for the meta-analysis. No association between the VNTR polymorphism and adult ADHD was seen in the full ADHD sample (Table III), even if gender or clinical subtypes were taken into account (data not shown). 
TABLE II. Genetic Effect of the DRD4 dup120bp Polymorphism on Adulthood ADHD

(a) Dominant model [LS + LL vs. SS]

\begin{tabular}{|c|c|c|c|c|c|c|c|c|c|c|}
\hline \multirow{2}{*}{\multicolumn{2}{|c|}{ OR M-H, fixed, $95 \% \mathrm{Cl}$}} & \multirow{3}{*}{$\begin{array}{r}\text { Study } \\
\text { 1. Germany }\end{array}$} & \multicolumn{2}{|c|}{ Cases } & \multicolumn{2}{|c|}{ Controls } & \multirow{3}{*}{$\begin{array}{c}\text { Weight [\%] } \\
32.82\end{array}$} & \multirow{3}{*}{$\begin{array}{c}\text { OR M-H, fixed, } 95 \% \text { Cl } \\
1.15(0.61-2.17)\end{array}$} & \multirow{3}{*}{$\mathbf{z}$} & \multirow{3}{*}{$P$-value } \\
\hline & & & \multirow{2}{*}{$\begin{array}{l}\text { SS } \\
22\end{array}$} & \multirow{2}{*}{$\begin{array}{r}\text { Total } \\
515\end{array}$} & \multirow{2}{*}{$\begin{array}{l}\text { SS } \\
18\end{array}$} & \multirow{2}{*}{$\begin{array}{r}\text { Total } \\
483\end{array}$} & & & & \\
\hline ommary & 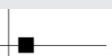 & & & & & & & & & \\
\hline Mentelante & . & 2. Netherlands & 6 & 189 & 13 & 485 & 13.03 & $1.19(0.44-3.17)$ & & \\
\hline nowerer & & 3. Norway & 6 & 448 & 11 & 464 & 19.68 & $0.55(0.20-1.52)$ & & \\
\hline soon & & 4. Spain & 7 & 295 & 30 & 630 & 34.48 & $0.48(0.20-1.12)$ & & \\
\hline Fixed eff & & Fixed-effects model & 41 & 1,447 & 72 & 2,062 & 100 & $0.81(0.54-1.21)$ & -1.02 & 0.30 \\
\hline 02 & 2.0 & Test of heterogeneit & $: Q=$ & $3.74, \mathrm{df}$ & 2 & $=0.29$ & $=19.7 \%$ & 87.7\%) & & \\
\hline
\end{tabular}

(b) Recessive model (LL vs. LS + SS )

\begin{tabular}{|c|c|c|c|c|c|c|c|c|c|c|}
\hline \multirow{2}{*}{\multicolumn{2}{|c|}{$\mathrm{OR} \mathrm{M}-\mathrm{H}$, fixed, $95 \% \mathrm{Cl}$}} & \multirow{3}{*}{$\begin{array}{l}\text { Study } \\
\text { 1. Germany }\end{array}$} & \multicolumn{2}{|c|}{ Cases } & \multicolumn{2}{|c|}{ Controls } & \multirow{3}{*}{$\begin{array}{c}\text { Weight [\%] } \\
32.69\end{array}$} & \multirow{3}{*}{$\begin{array}{c}\text { OR M-H, fixed, } 95 \% \mathrm{CI} \\
0.96(0.73-1.25)\end{array}$} & \multirow{3}{*}{$\mathbf{z}$} & \multirow{3}{*}{$P$-value } \\
\hline & & & \multirow{2}{*}{$\begin{array}{l}\text { LL } \\
356\end{array}$} & \multirow{2}{*}{$\begin{array}{r}\text { Total } \\
515\end{array}$} & \multirow{2}{*}{$\begin{array}{l}\text { LL } \\
338\end{array}$} & \multirow{2}{*}{$\begin{array}{r}\text { Total } \\
483\end{array}$} & & & & \\
\hline comang & & & & & & & & & & \\
\hline nenteranis & & 2. Netherlands & 139 & 189 & 351 & 485 & 15.81 & $1.06(0.72-1.55)$ & & \\
\hline nomer & - & 3. Norway & 344 & 448 & 355 & 464 & 23.19 & $1.27(0.94-1.71)$ & & \\
\hline Som & & 4. Spain & 190 & 295 & 411 & 630 & 28.32 & $0.96(0.72-1.28)$ & & \\
\hline & & Fixed-effects model & 1,029 & 1,447 & 1,455 & 2,062 & 100 & $1.05(0.90-1.22)$ & 0.63 & 0.52 \\
\hline 0.8 & ${ }^{10}$ Odds Ratio & Test of heterogeneit & $0=2$ & $36, \mathrm{df}=$ & $3, P=0$ & $50 ; 1^{2}=$ & $=0 \%(0-80.5 \%$ & & & \\
\hline
\end{tabular}

(c) Overdominant model (LS vs. LL + SS)

\begin{tabular}{|c|c|c|c|c|c|c|c|c|c|c|c|}
\hline \multirow{2}{*}{\multicolumn{2}{|c|}{ OR M-H, fixed, $95 \% \mathrm{Cl}$}} & & \multirow{3}{*}{$\begin{array}{r}\text { Study } \\
\text { 1. Germany }\end{array}$} & \multicolumn{2}{|c|}{ Cases } & \multicolumn{2}{|c|}{ Controls } & \multirow{3}{*}{$\begin{array}{c}\text { Weight (\%) } \\
30.13\end{array}$} & \multirow{3}{*}{$\begin{array}{c}\text { OR M-H, fixed, } 95 \% \mathrm{Cl} \\
1.01(0.76-1.34)\end{array}$} & \multirow{3}{*}{$\mathbf{z}$} & \multirow{3}{*}{$P$-value } \\
\hline & & & & \multirow{2}{*}{$\begin{array}{l}\text { LS } \\
137\end{array}$} & \multirow{2}{*}{$\begin{array}{r}\text { Total } \\
515\end{array}$} & \multirow{2}{*}{$\begin{array}{l}\text { LS } \\
127\end{array}$} & \multirow{2}{*}{$\begin{array}{r}\text { Total } \\
483\end{array}$} & & & & \\
\hline comarary & & & & & & & & & & & \\
\hline nemerenans & & & 2. Netherlands & 44 & 189 & 121 & 485 & 16.30 & $0.91(0.61-1.35)$ & & \\
\hline nonvay & - & & 3. Norway & 98 & 448 & 118 & 464 & 28.36 & $0.82(0.60-1.11)$ & & \\
\hline $\operatorname{sanh}$ & $\square$ & - & 4. Spain & 98 & 295 & 189 & 630 & 25.21 & $1.16(0.86-1.56)$ & & \\
\hline Fixede & nodel & & Fixed-effects model & 377 & 1,447 & 555 & 2,062 & 100 & $0.98(0.83-1.14)$ & -0.24 & 0.80 \\
\hline & $0.8 \underset{\substack{10 \\
\text { Odds Reta }}}{10}$ & $14 \quad 1.6$ & Test of heterogeneity & $y: Q=z$ & $2.72, \mathrm{df}=$ & $=3, P$ & $=0.43 ;$ & ${ }^{2}=0 \%(0-83$ & $.1 \%]$ & & \\
\hline
\end{tabular}

\section{Multiple-Marker Analysis}

Linkage disequilibrium between the two studied polymorphisms in DRD4 was assessed and shown to be negligible $(P=0.99)$. Genotypes from 1,246 patients $(77 \%)$ and 1,835 controls $(78 \%)$ were available for the two DRD4 polymorphisms. Table IV summarizes the estimated haplotype frequencies for the four populations considered in the study. The comparison of haplotype frequencies between cases and controls showed no association in any of the four separate cohorts. We subsequently performed a meta-analysis considering carriers of the three common DRD4 haplotypes, S-4R, L-4R, and L-7R, and, after discarding the presence of 
TABLE III. Genetic Effect of the DRD4 48bpVNTR Polymorphism on Adulthood ADHD

(a) Comparison of the 4R4R genotype versus others

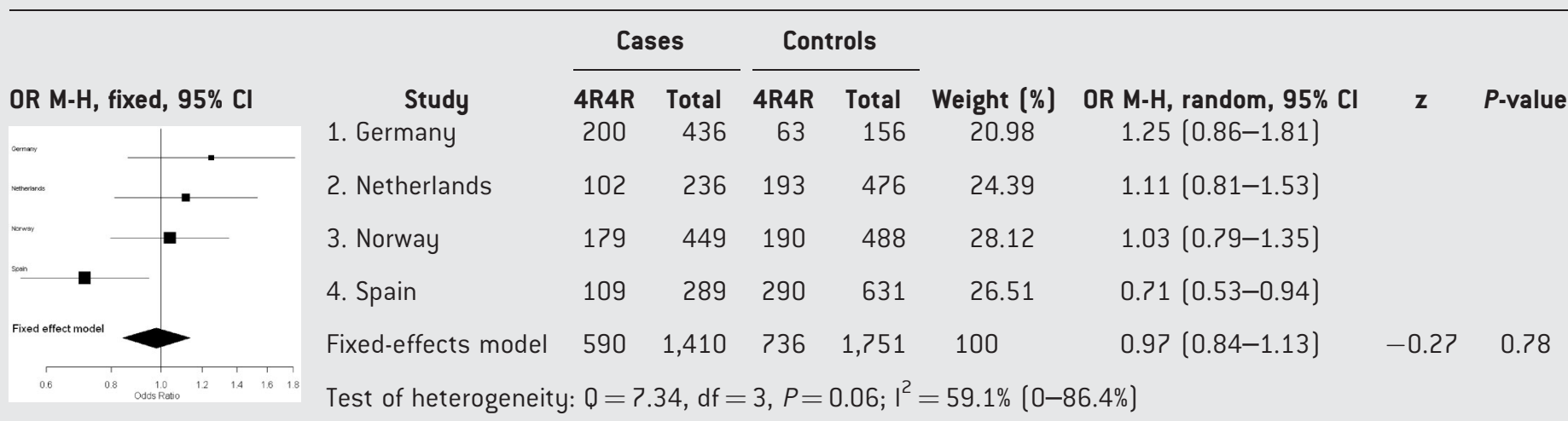

(b) Comparison of PR?R genotypes versus others

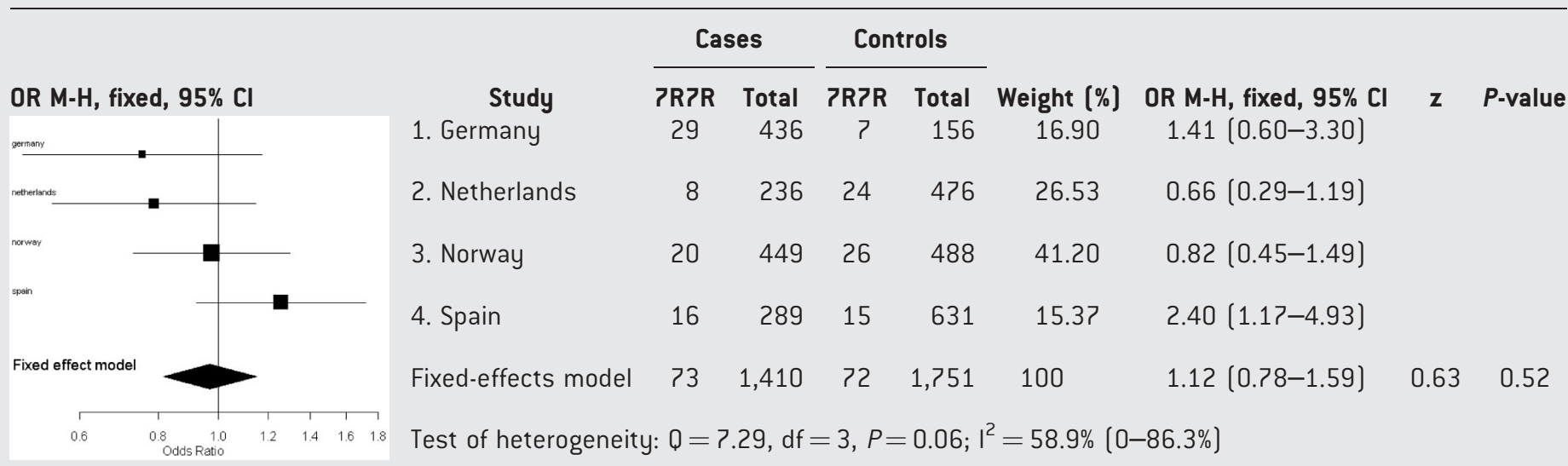

(c) Comparison of the $4 R 7 R$ genotypes versus others

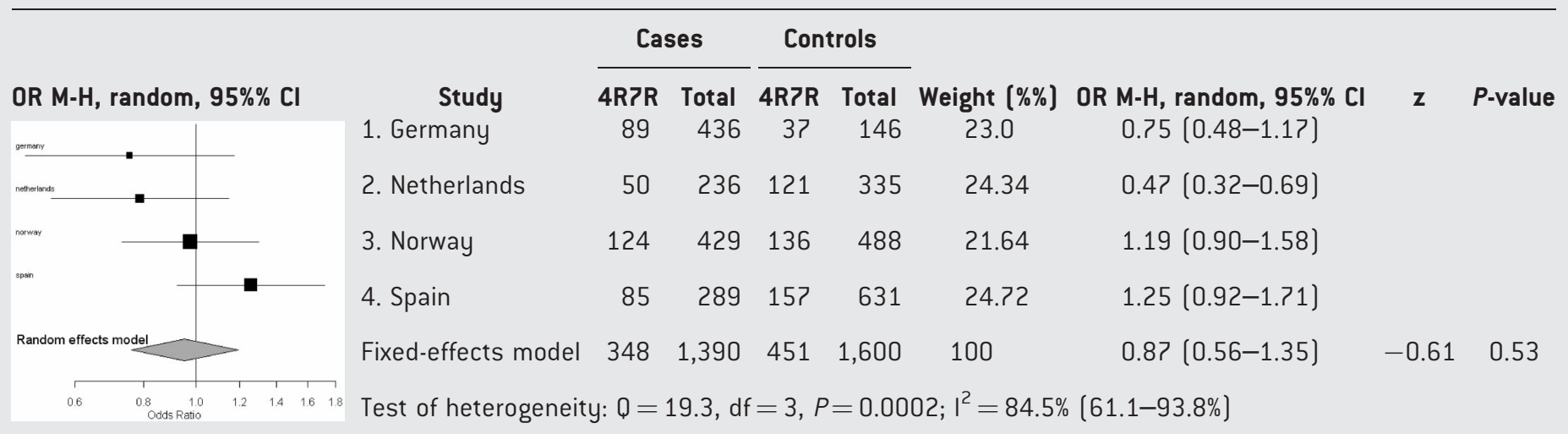

4R: 4 repeats of the DRD4 48bpVNTR polymorphism; ?R: ? repeats of the DRD4 48bpVNTR polymorphism.

heterogeneity between the four samples using the Q-statistic, we observed an under-representation of the S-4R allelic combination in the ADHD sample $[P=0.01 ; \mathrm{OR}=0.78(0.65-0.95)$; Table IV]. We also performed multiple comparisons stratifying by gender and by clinical subtype and confirmed these differences in females
$[P=0.04$, OR $=0.73 \quad(0.54-0.99) ;$ Supplementary Table SV $]$. Interestingly, when we considered patients with the ADHD combined subtype only, we observed an increased frequency of carriers of the $\mathrm{L}-4 \mathrm{R}$ risk haplotype $[P=0.02 ; \mathrm{OR}=1.29$ (1.04-1.61)] in addition to an under-representation of the S-4R 
TABLE IV. Pooled Analysis Considering S-4R Carriers of the DRD4 dup120bp-48bp VNTR Haplotype in 1,246 Adulthood ADHD Patients and 1,835 Controls

\begin{tabular}{|c|c|c|c|c|c|c|c|c|c|c|}
\hline \multirow{2}{*}{\multicolumn{2}{|c|}{ OR M-H, fixed, $95 \% \mathrm{Cl}$}} & & \multicolumn{2}{|c|}{ Cases } & \multicolumn{2}{|c|}{ Controls } & \multirow{3}{*}{$\begin{array}{c}\text { Weight [\%] } \\
16.69\end{array}$} & \multirow{3}{*}{$\begin{array}{c}\text { OR M-H, fixed, } 95 \% \text { Cl } \\
0.59(0.65-0.96)\end{array}$} & \multirow{3}{*}{$\mathbf{z}$} & \multirow{3}{*}{$P$-value } \\
\hline & & Study & $S-4 R$ & Total & S-4R & Total & & & & \\
\hline cemary & & 1. Germany & 60 & 327 & 33 & 120 & & & & \\
\hline Netholiands & & 2. Netherlands & 32 & 187 & 99 & 478 & 19.53 & 0.79 (0.50-1.22) & & \\
\hline Nemays & & 3. Norway & 67 & 443 & 91 & 544 & 29.34 & 0.88 (0.62-1.25) & & \\
\hline E & - & 4. Spain & 62 & 289 & 176 & 693 & 34.44 & $0.80(0.57-1.11)$ & & \\
\hline Fixed effect model & & Fixed-effects model & 221 & 1,246 & 399 & 1,835 & 100 & $0.78(0.65-0.95)$ & -2.39 & 0.01 \\
\hline${ }_{\text {Odds Ratio }}^{0.8}{ }^{0.8}$ & 12 & Test of heterogeneity & $0=1$ & $.78, \mathrm{df}$ & $=3, P=$ & $=0.62 ; 1^{2}$ & ${ }^{2}=0 \%(0-74$ & $1 \%)$ & & \\
\hline
\end{tabular}

allelic combination $[P=0.01 \mathrm{OR}=0.75(0.60-0.94)]$ in this clinical dataset (Table V).

\section{Interaction Between DRD4 and SLC6A3}

Since we previously described an association of adulthood ADHD with the SLC6A3 9R-6R haplotype (3'UTR VNTR-intron 8 VNTR) in the same dataset [Franke et al., 2010], we further tested for gene $\times$ gene interactions between the ADHD-associated haplotypes of DRD4 and SLC6A3. Genotypes from 1,208 patients (75\%) and 1,290 controls (55\%) were available for the four polymorphisms in the two genes. Although no evidence for epistatic effects was detected, the simultaneous presence of the two risk haplotypes, DRD4 L-4R and SLC6A3 9R-6R, increased the risk for ADHD in both the ADHD sample as a whole $[P=3.04 \mathrm{e}-05$; OR $1.66(1.31-2.11)]$ and in the combined clinical subtype $[P=2.66 \mathrm{e}-05 ; \mathrm{OR}=1.74(1.35-2.26)]$. Thus, the OR for ADHD subjects carrying the DRD4 L-4R haplotype rose from 1.09 $(0.90-1.32)$ to $1.66(1.31-2.11)$ in those patients also carrying the SLC6A39R-6R allelic combination. Similar results were obtained in the combined type ADHD clinical subtype (Fig. 1) and indicate additive effects between risk haplotypes at these two loci.

\section{DISCUSSION}

In the present study we performed a meta-analysis in a large sample of 1,608 adulthood ADHD patients and 2,352 unrelated controls from four European countries to evaluate the role of the DRD4 dup120bp and 48bpVNTR polymorphisms in the persistent form of the disorder. Although nominal association with dup120bp was observed in some of the populations considered in this study, no evidence for a role of either polymorphism in ADHD was detected when they were considered separately in the entire sample. The multiple-marker analysis, however, supports a contribution of the L-4R (dup120bp-48bpVNTR) haplotype to adulthood ADHD, mainly to the combined clinical subtype, although these findings should be viewed with caution given the many (albeit highly correlated) statistical tests performed. These results support a connection between DRD4 and the persistence of the ADHD symptoms across the life span, in line with previous follow-up studies [Biederman et al., 2009].

Many association studies between DRD4 and ADHD have been performed, although results are often controversial. In this regard, although our data in the single-marker analysis are in agreement with previous reports showing no association between ADHD and the 48bpVNTR polymorphism [Roman et al., 2001; Todd et al., 2001; Bakker et al., 2005; Brookes et al., 2005; Carrasco et al., 2006; Johansson et al., 2008; Sonuga-Barke et al., 2008], they are contrary to others having reported on association between the $7 \mathrm{R}$ allele and the disorder [Rowe et al., 1998; Faraone et al., 2001; Maher et al., 2002; Wohl et al., 2005; Brookes et al., 2006; Li et al., 2006; Gizer et al., 2008, 2009; Biederman et al., 2009; Langley et al., 2009; Nikolaidis and Gray, 2010]. Likewise, our results for the DRD4 dup120bp polymorphism are in line with most of the literature, including a recent meta-analysis [Barr et al., 2001; Todd et al., 2001; Mill et al., 2003; Kirley et al., 2004; Brookes et al., 2005; Bhaduri et al., 2006; Gizer et al., 2009], but not with findings from the first two association analyses of this variation [McCracken et al., 2000].

Due to the heterogeneity of populations, methodologies and statistical tests used, it is difficult to establish direct comparisons between all these reports. In the case of the 48bpVNTR, allele frequencies of this multiallelic polymorphism vary considerably across ethnic groups. The $4 \mathrm{R}$ allele is the most prevalent one and appears in all populations. However, $7 \mathrm{R}$ is frequent among Americans but rare among Asians and $2 \mathrm{R}$ is frequent in Asia but uncommon among Americans [Van Tol et al., 1992; Chang et al., 1996; Ding et al., 2000; Wang et al., 2004]. In addition, some studies collapse different alleles into long and short categories $(6 \mathrm{R}-8 \mathrm{R}$ vs. 2R-5R) [Eisenberg et al., 2000; Manor et al., 2002] and others only consider the most frequent alleles among Caucasians ( $4 \mathrm{R}$ and $7 \mathrm{R}$ ) [Roman et al., 2001; Bellgrove et al., 2005]. Because grouping several frequent alleles in a single category or considering only 
TABLE V. Pooled Analysis Considering the [a] S-4R and (b) L-4R Carriers of the DRD4 dup120bp-48bpVNTR Haplotype in 788 Combined ADHD Patients and 1,835 Controls

[a] S-4R

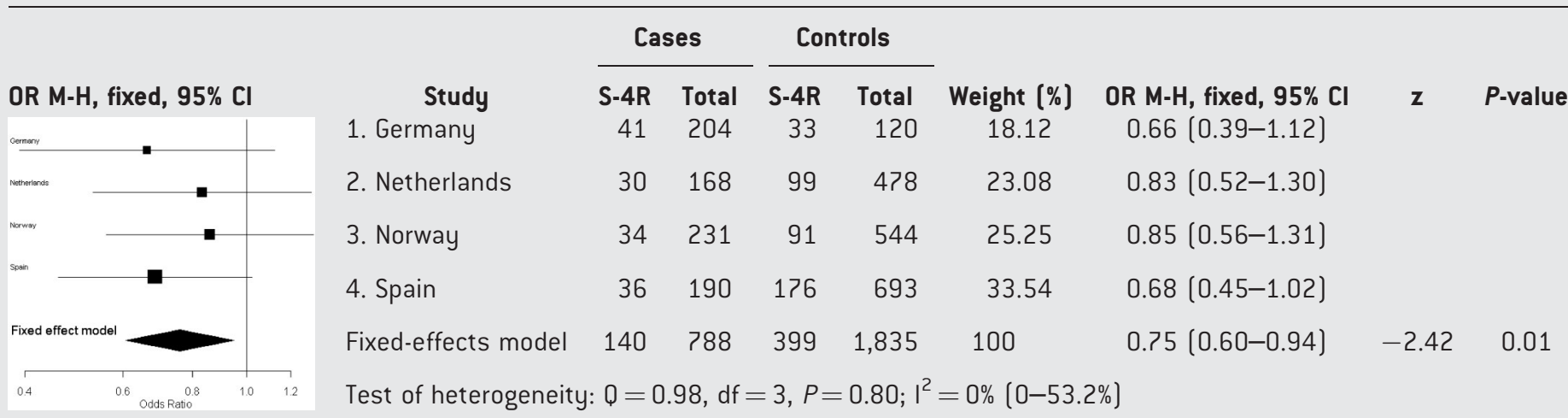

(b) L-4R

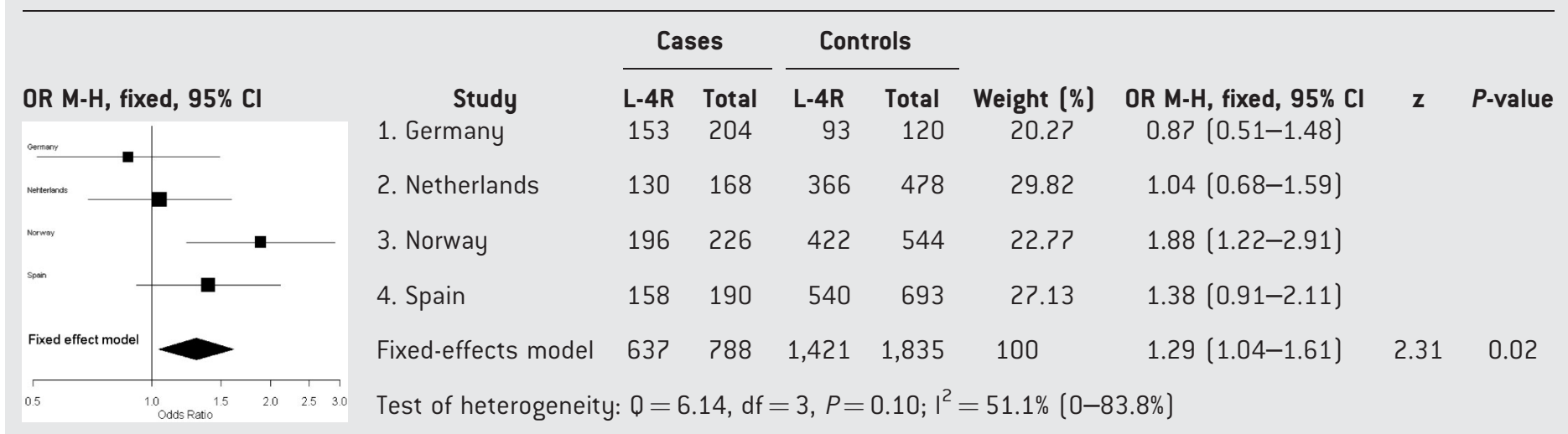

S, short allele of the dup120bp polymorphism (120 bp); L, Long allele of the dup120bp polymorphism ( $240 \mathrm{bp}$ ); $4 \mathrm{R}$, 4 repeats of the $48 \mathrm{bpVNTR}$ polymorphism.

variants described in previous analyses may result in loss of crucial genetic information, we included all frequent alleles separately and grouped the less frequent variants $(<5 \%)$ into a single group.

Several other explanations could also account for the inconsistent findings observed among previously reported DRD4 studies. Differences in sample size, comorbidities, and proportions of clinical subtypes or genders may result in discordant results. Limited sample sizes may provide imprecise or incorrect estimates of the magnitude of the observed effects. The present meta-analysis provides an adequate statistical power $(>99 \%)$ to detect an association of small effect. Additionally, in the case of gender-specific associations, differences in the male:female proportion among studies may also contribute to variability. In this regard, although nominal and site-specific, we found male-specific association signals in the Norwegian sample when samples were stratified according to gender. Whether the different ADHD clinical subtypes share genetic risk factors has been still poorly explored. The association between ADHD and the DRD4 risk haplotype detected in the present study was observed in the combined but not in the inattentive clinical subtype. Our results are in agreement with previous studies supporting the validity of the different DSM-IV subtypes, mainly the combined subtype, and suggesting the participation of differential genetic factors in distinct ADHD clinical groups [Rasmussen et al., 2004; Larsson et al., 2006; Sobanski et al., 2008; Ribasés et al., 2009]. Interestingly, Smith [2010] performed a meta-analysis of 28 association studies between ADHD and the 48bvNTR in DRD4 and observed that increases in the proportion of combined ADHD patients within an ADHD sample were associated with an increase in the magnitude of the effect. These results are consistent with the hypothesis that DRD4 is more strongly associated with combined ADHD than with inattentive ADHD and are in line with the hypothesis that hypofunctioning in mesocortical and mesolimbic dopaminergic pathways better characterize the etiology of combined ADHD than inattentive ADHD [Sagvolden et al., 2005; Smith, 2010]. This view is supported by the fact that variation in DAT1, another dopaminergic gene, is also more strongly associated with combined ADHD than with inattentive ADHD (e.g., Waldman et al., 1998). Moroeover, it is possible that consideration of neuropsychological traits, comorbidities or personality data, not included in the present study, may help in the future to obtain better association signals with DRD4 than the analysis of the sole ADHD condition. Finally, since most of 

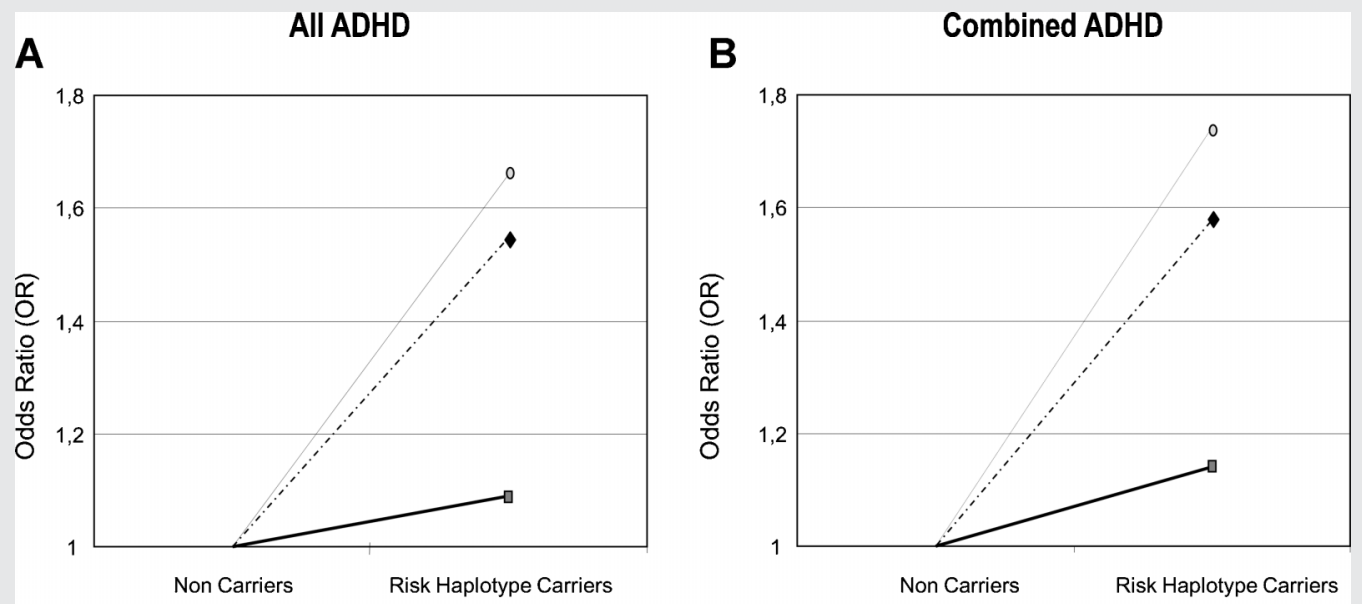

$0 . \cdots \quad$ DRD4 (L-4R) Carriers $\rightarrow-S L C 6 A 3(9 R-6 R)$ Carriers $\quad-\uparrow \quad$ DRD4 (L-4R) + SLC6A3 (9R-6R) Carriers

FIG. 1. Graphical representation showing the analysis of gene $\times$ gene interactions between the DRD4 and SLC6A3 genes. The simultaneous presence of the two risk haplotypes, DRD4 L-4R and SLC6A3 9R-6R, increased the risk for ADHD in both the pooled ADHD sample [A] and the combined clinical subtype sample $[B]$. These results suggest additive effects of the risk haplotypes at these two loci on ADHD.

previous research on the DRD4 gene has focused on childhood patients (only four studies having considered the 48bpVNTR polymorphism in adulthood ADHD [Muglia et al., 2000; Smith et al., 2003; Boonstra et al., 2008; Johansson et al., 2008], differential proportion of remitting and persisting ADHD within the children samples may also explain discordant results among studies [Brookes et al., 2006; Gornick et al., 2007; Langley et al., 2009]. In this regard, Shaw et al. [2007] showed in a longitudinal study that the $7 \mathrm{R}$ allele was associated with a better clinical outcome and with differences in cortical thickness in regions that are important in attention control. These neuroanatomical changes were most apparent early in development and resolved by late adolescence. In addition, Johansson et al. [2008] showed a trend towards protective effects of the 7R allele in adults with ADHD, results that suggest a different effect of the 7R allele in child and adulthood ADHD and could explain previous controversial results. However, another recent study by Biederman et al. [2009] showed increased risk of ADHD persistence due to the $7 \mathrm{R}$ allele.

The identification of different alleles at the same markers as susceptibility factors for ADHD in several studies and the failure to consistently replicate positive associations suggest that the dup120bp and the 48bpVNTR polymorphisms may not be themselves the causative variants that increase disease risk but are in linkage disequilibrium with a true causative variant within the same gene. Further deep-sequencing of this genomic region may allow identification of the functional DRD4 variants directly involved in the genetic background of ADHD. In that regard, it is interesting to note that an increased burden of rare variants has been observed in the 7R allele of DRD4 in children with ADHD [Grady et al., 2003].

In addition, we detected preliminary evidence of additive, but not epistatic, effects for DRD4 and SLC6A3 in ADHD. Since
SLC6A3 is expressed in subcortical regions whereas DRD4 is expressed in frontal cortex, the two genes may indeed be expected to increase ADHD risk by acting in independent pathways [Durston et al., 2005]. However, it is difficult to draw a final conclusion about the combined participation of these two genes in ADHD symptomatology as several studies have described discordant results [Roman et al., 2001; Kim et al., 2005; Carrasco et al., 2006; Qian et al., 2007; Gabriela et al., 2009].

In summary, the results of the present study showed nominal association between the L-4R haplotype (dup120bp-48bpVNTR) and adulthood combined ADHD through a meta-analysis of four European populations. Our results also suggest an additive effect between this DRD4 risk haplotype and SLC6A3. Replication in other datasets is warranted to confirm these results and to better understand the involvement of the DRD4 and SLC6A3 genes in the predisposition to the persistent form of ADHD.

\section{ACKNOWLEDGMENTS}

Spain: We are grateful to patients and controls for they participation in the study, to M. Dolors Castellar and A. Daví for their help in the recruitment of control subjects and to Dr. Nuria Gómez, Dr. Gloria Palomar and Mariana Nogueira for patients' assessment. M. Ribasés is a recipient of a "Miguel de Servet" contract from the "Instituto de Salud Carlos III", "Ministerio de Ciencia e Innovación", Spain and N. Fernàndez-Castillo has an APIF contract from the University of Barcelona. Financial support was received from "Instituto de Salud Carlos III-FIS," Spain (PI040524, PI041267, PI080519), "Fundació La Marató de TV3" (ref. 092330/ 31), "Agència de Gestió d'Ajuts Univeristaris i de RecercaAGAUR" (2009SGR-00971), Obra Social - Fundació "La Caixa" (2007-2010) and the Subdirecció General de Drogodependències 
(Departament de Salut) and Pla Director de Salut Mental i Addiccions of the Catalonia Government (Generalitat de Catalunya). The Netherlands: We thank Cornelis C. Kan, Marije Boonstra, and Marten Onnink for help with patient inclusion, as well as Marlies Naber and Angelien Heister for DNA handling and genotyping. The Dutch controls were derived from the Nijmegen Biomedical Study. Principal investigators of the Nijmegen Biomedical Study are L.A.L.M. Kiemeney, M. den Heijer, A.L.M. Verbeek, D.W. Swinkels, and B. Franke. The Dutch part of the project was supported by the Hersenstichting Nederland (Fonds Psychische Gezondheid). Norway: We thank Paal Borge and Sigrid Erdal at Haukeland University Hospital for help with genotyping. The study was supported by the Research Council of Norway, Western Norway Regional Health Authority, The National Research Network for ADHD, and The University of Bergen. Germany: We thank T. Töpner, N. Steigerwald, C. Gagel, N. Döring, and J. Auer for excellent technical assistance. Our research was supported by the DFG (Grant RE1632/1-5 to A.R.; KFO 125 to A.R. and K.P.L.; SFB TRR 58/A1,5 to K.P.L. and Z02 to A.R.; GRK 1156 and GK emotions to K.P.L.), BMBF (01GV0605 to K.P.L.), and the EC (NEWMOOD LSHM-CT-2003-503474 to K.P.L.).

\section{REFERENCES}

Arcos-Burgos M, Castellanos FX, Konecki D, Lopera F, Pineda D, Palacio JD, Rapoport JL, Berg K, Bailey-Wilson J, Muenke M. 2004. Pedigree disequilibrium test (PDT) replicates association and linkage between DRD4 and ADHD in multigenerational and extended pedigrees from a genetic isolate. Mol Psychiatry 9(3):252-259.

Asghari V, Sanyal S, Buchwaldt S, Paterson A, Jovanovic V, Van Tol HH. 1995. Modulation of intracellular cyclic AMP levels by different human dopamine D4 receptor variants. J Neurochem 65(3):1157-1165.

Auerbach JG, Atzaba-Poria N, Berger A, Landau R, Arbelle S, Raz Y, Ebstein R. 2010. Dopamine risk and paternal ADHD symptomatology associated with ADHD symptoms in four and a half-year-old boys. Psychiatr Genet 20(4):160-165.

Bakker SC, van der Meulen EM, Oteman N, Schelleman H, Pearson PL, Buitelaar JK, Sinke RJ. 2005. DAT1, DRD4, and DRD5 polymorphisms are not associated with ADHD in Dutch families. Am J Med Genet Part B $132 \mathrm{~B}(1): 50-52$.

Barr CL, Feng Y, Wigg KG, Schachar R, Tannock R, Roberts W, Malone M, Kennedy JL. 2001. 5'-Untranslated region of the dopamine D4 receptor gene and attention-deficit hyperactivity disorder. Am J Med Genet 105(1):84-90.

Bellgrove MA, Hawi Z, Lowe N, Kirley A, Robertson IH, Gill M. 2005. DRD4 gene variants and sustained attention in attention deficit hyperactivity disorder (ADHD): Effects of associated alleles at the VNTR and 521 SNP. Am J Med Genet Part B 136B(1):81-86.

Bhaduri N, Das M, Sinha S, Chattopadhyay A, Gangopadhyay PK, Chaudhuri K, Singh M, Mukhopadhyay K. 2006. Association of dopamine D4 receptor (DRD4) polymorphisms with attention deficit hyperactivity disorder in Indian population. Am J Med Genet Part B 141B(1):61-66.

Biederman J, Petty CR, Ten Haagen KS, Small J, Doyle AE, Spencer T, Mick E, Monuteaux MC, Smoller JW, Faraone SV. 2009. Effect of candidate gene polymorphisms on the course of attention deficit hyperactivity disorder. Psychiatry Res 170(2-3):199-203.

Boonstra AM, Kooij JJ, Buitelaar JK, Oosterlaan J, Sergeant JA, Heister JG, Franke B. 2008. An exploratory study of the relationship between four candidate genes and neurocognitive performance in adult ADHD. Am J Med Genet Part B 147(3):397-402.

Brookes KJ, Xu X, Chen CK, Huang YS, Wu YY, Asherson P. 2005. No evidence for the association of DRD4 with ADHD in a Taiwanese population within-family study. BMC Med Genet 6:31.

Brookes K, Xu X, Chen W, Zhou K, Neale B, Lowe N, Anney R, Franke B, Gill M, Ebstein R, Buitelaar J, Sham P, Campbell D, Knight J, Andreou P, Altink M, Arnold R, Boer F, Buschgens C, Butler L, Christiansen H, Feldman L, Fleischman K, Fliers E, Howe-Forbes R, Goldfarb A, Heise A, Gabriels I, Korn-Lubetzki I, Johansson L, Marco R, Medad S, Minderaa R, Mulas F, Muller U, Mulligan A, Rabin K, Rommelse N, Sethna V, Sorohan J, Uebel H, Psychogiou L, Weeks A, Barrett R, Craig I, Banaschewski T, Sonuga-Barke E, Eisenberg J, Kuntsi J, Manor I, McGuffin P, Miranda A, Oades RD, Plomin R, Roeyers H, Rothenberger A, Sergeant J, Steinhausen HC, Taylor E, Thompson M, Faraone SV, Asherson P. 2006. The analysis of 51 genes in DSM-IV combined type attention deficit hyperactivity disorder: Association signals in DRD4, DAT1 and 16 other genes. Mol Psychiatry 11(10):934-953.

Carrasco X, Rothhammer P, Moraga M, Henriquez H, Chakraborty R, Aboitiz F, Rothhammer F. 2006. Genotypic interaction between DRD4 and DAT1 loci is a high risk factor for attention-deficit/ hyperactivity disorder in Chilean families. Am J Med Genet Part B $141 \mathrm{~B}(1): 51-54$.

Castellanos FX, Lau E, Tayebi N, Lee P, Long RE, Giedd JN, Sharp W, Marsh WL, Walter JM, Hamburger SD, Ginns EI, Rapoport JL, Sidransky E. 1998. Lack of an association between a dopamine-4 receptor polymorphism and attention-deficit/hyperactivity disorder: Genetic and brain morphometric analyses. Mol Psychiatry 3(5):431-434.

Chang FM, Kidd JR, Livak KJ, Pakstis AJ, Kidd KK. 1996. The world-wide distribution of allele frequencies at the human dopamine D4 receptor locus. Hum Genet 98(1):91-101.

Comings DE, Gonzalez N, Wu S, Gade R, Muhleman D, Saucier G, Johnson P, Verde R, Rosenthal RJ, Lesieur HR, Rugle LJ, Miller WB, MacMurray JP. 1999. Studies of the $48 \mathrm{bp}$ repeat polymorphism of the DRD4 gene in impulsive, compulsive, addictive behaviors: Tourette syndrome, ADHD, pathological gambling, and substance abuse. Am J Med Genet 88(4): $358-368$.

Curran S, Mill J, Sham P, Rijsdijk F, Marusic K, Taylor E, Asherson P. 2001. QTL association analysis of the DRD4 exon 3 VNTR polymorphism in a population sample of children screened with a parent rating scale for ADHD symptoms. Am J Med Genet 105(4):387-393.

Ding YC, Wooding S, Harpending HC, Chi HC, Li HP, Fu YX, Pang JF, Yao YG, Yu JG, Moyzis R, Zhang Y. 2000. Population structure and history in East Asia. Proc Natl Acad Sci USA 97(25):14003-14006.

D’Souza UM, Russ C, Tahir E, Mill J, McGuffin P, Asherson PJ, Craig IW. 2004. Functional effects of a tandem duplication polymorphism in the 5 flanking region of the DRD4 gene. Biol Psychiatry 56(9):691-697.

Durston S, Fossella JA, Casey BJ, Hulshoff Pol HE, Galvan A, Schnack HG, Steenhuis MP, Minderaa RB, Buitelaar JK, Kahn RS, van Engeland H. 2005. Differential effects of DRD4 and DAT1 genotype on fronto-striatal gray matter volumes in a sample of subjects with attention deficit hyperactivity disorder, their unaffected siblings, and controls. Mol Psychiatry 10(7):678-685.

Eisenberg J, Zohar A, Mei-Tal G, Steinberg A, Tartakovsky E, Gritsenko I, Nemanov L, Ebstein RP. 2000. A haplotype relative risk study of the dopamine D4 receptor (DRD4) exon III repeat polymorphism and attention deficit hyperactivity disorder (ADHD). Am J Med Genet 96(3):258-261.

Ernst M, Zametkin AJ, Matochik JA, Pascualvaca D, Jons PH, Cohen RM. 1999. High midbrain [18F]DOPA accumulation in children with attention deficit hyperactivity disorder. Am J Psychiatry 156(8):1209-1215. 
Faraone SV, Mick E. 2010. Molecular genetics of attention deficit hyperactivity disorder. Psychiatr Clin North Am 33(1):159-180.

Faraone SV, Doyle AE, Mick E, Biederman J. 2001. Meta-analysis of the association between the 7-repeat allele of the dopamine $\mathrm{D}(4)$ receptor gene and attention deficit hyperactivity disorder. Am J Psychiatry 158(7): 1052-1057.

Faraone SV, Perlis RH, Doyle AE, Smoller JW, Goralnick JJ, Holmgren MA, Sklar P. 2005. Molecular genetics of attention-deficit/hyperactivity disorder. Biol Psychiatry 57(11):1313-1323.

Faraone SV, Biederman J, Mick E. 2006. The age-dependent decline of attention deficit hyperactivity disorder: A meta-analysis of follow-up studies. Psychol Med 36(2):159-165.

Franke B, Vasquez AA, Johansson S, Hoogman M, Romanos J, BoreattiHummer A, Heine M, Jacob CP, Lesch KP, Casas M, Ribases M, Bosch R, Sanchez-Mora C, Gomez-Barros N, Fernandez-Castillo N, Bayes M, Halmoy A, Halleland H, Landaas ET, Fasmer OB, Knappskog PM, Heister AJ, Kiemeney LA, Kooij JJ, Boonstra AM, Kan CC, Asherson P, Faraone SV, Buitelaar JK, Haavik J, Cormand B, Ramos-Quiroga JA, Reif A. 2010. Multicenter analysis of the SLC6A3/DAT1 VNTR haplotype in persistent $\mathrm{ADHD}$ suggests differential involvement of the gene in childhood and persistent ADHD. Neuropsychopharmacology 35(3):656-664.

Gabriela ML, John DG, Magdalena BV, Ariadna GS, de Francisco LP, Liz SM, Lino PC, Josefina RG, Ernesto RZ, Carlos CF. 2009. Genetic interaction analysis for DRD4 and DAT1 genes in a group of Mexican ADHD patients. Neurosci Lett 451(3):257-260.

Gizer IR, Waldman ID, Abramowitz A, Barr CL, Feng Y, Wigg KG, Misener VL, Rowe DC. 2008. Relations between multi-informant assessments of ADHD symptoms, DAT1, and DRD4. J Abnorm Psychol 117(4): 869-880.

Gizer IR, Ficks C, Waldman ID. 2009. Candidate gene studies of ADHD: A meta-analytic review. Hum Genet 126(1):51-90.

Gonzalez JR, Armengol L, Sole X, Guino E, Mercader JM, Estivill X, Moreno V. 2007. SNPassoc: An R package to perform whole genome association studies. Bioinformatics 23(5):644-645.

Gornick MC, Addington A, Shaw P, Bobb AJ, Sharp W, Greenstein D, Arepalli S, Castellanos FX, Rapoport JL. 2007. Association of the dopamine receptor D4 (DRD4) gene 7-repeat allele with children with attention-deficit/hyperactivity disorder (ADHD): An update. Am J Med Genet Part B 144B(3):379-382.

Grady DL, Chi HC, Ding YC, Smith M, Wang E, Schuck S, Flodman P, Spence MA, Swanson JM, Moyzis RK. 2003. High prevalence of rare dopamine receptor $\mathrm{D} 4$ alleles in children diagnosed with attention-deficit hyperactivity disorder. Mol Psychiatry 8(5):536-545.

Hawi Z, McCarron M, Kirley A, Daly G, Fitzgerald M, Gill M. 2000. No association of the dopamine DRD4 receptor (DRD4) gene polymorphism with attention deficit hyperactivity disorder (ADHD) in the Irish population. Am J Med Genet 96(3):268-272.

Johansson S, Halleland H, Halmoy A, Jacobsen KK, Landaas ET, Dramsdahl M, Fasmer OB, Bergsholm P, Lundervold AJ, Gillberg C, Hugdahl K, Knappskog PM, Haavik J. 2008. Genetic analyses of dopamine related genes in adult ADHD patients suggest an association with the DRD5microsatellite repeat, but not with DRD4 or SLC6A3 VNTRs. Am J Med Genet Part B 147B(8):1470-1475.

Kazmi MA, Snyder LA, Cypess AM, Graber SG, Sakmar TP. 2000. Selective reconstitution of human $\mathrm{D} 4$ dopamine receptor variants with $\mathrm{Gi}$ alpha subtypes. Biochemistry 39(13):3734-3744.

Kereszturi E, Kiraly O, Csapo Z, Tarnok Z, Gadoros J, Sasvari-Szekely M, Nemoda Z. 2007. Association between the 120-bp duplication of the dopamine $\mathrm{D} 4$ receptor gene and attention deficit hyperactivity disorder:
Genetic and molecular analyses. Am J Med Genet Part B 144B(2): 231-236.

Kim YS, Leventhal BL, Kim SJ, Kim BN, Cheon KA, Yoo HJ, Kim SJ, Badner J, Cook EH. 2005. Family-based association study of DAT1 and DRD4 polymorphism in Korean children with ADHD. Neurosci Lett 390(3):176-181.

Kirley A, Lowe N, Mullins C, McCarron M, Daly G, Waldman I, Fitzgerald M, Gill M, Hawi Z. 2004. Phenotype studies of the DRD4 gene polymorphisms in ADHD: Association with oppositional defiant disorder and positive family history. Am J Med Genet Part B 131B(1):38-42.

Kotler M, Manor I, Sever Y, Eisenberg J, Cohen H, Ebstein RP, Tyano S. 2000. Failure to replicate an excess of the long dopamine D4 exon III repeat polymorphism in ADHD in a family-based study. Am J Med Genet 96(3):278-281.

Kustanovich V, Ishii J, Crawford L, Yang M, McGough JJ, McCracken JT, Smalley SL, Nelson SF. 2004. Transmission disequilibrium testing of dopamine-related candidate gene polymorphisms in ADHD: Confirmation of association of ADHD with DRD4 and DRD5. Mol Psychiatry 9(7):711-717.

LaHoste GJ, Swanson JM, Wigal SB, Glabe C, Wigal T, King N, Kennedy JL. 1996. Dopamine D4 receptor gene polymorphism is associated with attention deficit hyperactivity disorder. Mol Psychiatry 1(2):121-124.

Laird NM, Mosteller F. 1990. Some statistical methods for combining experimental results. Int J Technol Assess Health Care 6(1):5-30.

Langley K, Marshall L, van den Bree M, Thomas H, Owen M, O’Donovan M, Thapar A. 2004. Association of the dopamine D4 receptor gene 7repeat allele with neuropsychological test performance of children with ADHD. Am J Psychiatry 161(1):133-138.

Langley K, Fowler TA, Grady DL, Moyzis RK, Holmans PA, van den Bree MB, Owen MJ, O’Donovan MC, Thapar A. 2009. Molecular genetic contribution to the developmental course of attention-deficit hyperactivity disorder. Eur Child Adolesc Psychiatry 18(1):26-32.

Lara C, Fayyad J, de Graaf R, Kessler RC, Aguilar-Gaxiola S, Angermeyer M, Demytteneare K, de Girolamo G, Haro JM, Jin R, Karam EG, Lepine JP, Mora ME, Ormel J, Posada-Villa J, Sampson N. 2009. Childhood predictors of adult attention-deficit/hyperactivity disorder: Results from the World Health Organization World Mental Health Survey Initiative. Biol Psychiatry 65(1):46-54.

Larsson H, Lichtenstein P, Larsson JO. 2006. Genetic contributions to the development of ADHD subtypes from childhood to adolescence. J Am Acad Child Adolesc Psychiatry 45:973-981.

Lau J, Ioannidis JP, Schmid CH. 1997. Quantitative synthesis in systematic reviews. Ann Intern Med 127(9):820-826.

Li D, Sham PC, Owen MJ, He L. 2006. Meta-analysis shows significant association between dopamine system genes and attention deficit hyperactivity disorder (ADHD). Hum Mol Genet 15(14):2276-2284.

Lichter JB, Barr CL, Kennedy JL, Van Tol HH, Kidd KK, Livak KJ. 1993. A hypervariable segment in the human dopamine receptor D4 (DRD4) gene. Hum Mol Genet 2(6):767-773.

Maher BS, Marazita ML, Ferrell RE, Vanyukov MM. 2002. Dopamine system genes and attention deficit hyperactivity disorder: A meta-analysis. Psychiatr Genet 12(4):207-215.

Manor I, Tyano S, Eisenberg J, Bachner-Melman R, Kotler M, Ebstein RP. 2002. The short DRD4 repeats confer risk to attention deficit hyperactivity disorder in a family-based design and impair performance on a continuous performance test (TOVA). Mol Psychiatry 7(7): 790-794.

Mantel N, Haenszel W. 1959. Statistical aspects of the analysis of data from retrospective studies of disease. J Natl Cancer Inst 22(4):719-748. 
McCracken JT, Smalley SL, McGough JJ, Crawford L, Del'Homme M, Cantor RM, Liu A, Nelson SF. 2000. Evidence for linkage of a tandem duplication polymorphism upstream of the dopamine $\mathrm{D} 4$ receptor gene (DRD4) with attention deficit hyperactivity disorder (ADHD). Mol Psychiatry 5(5):531-536.

Mill J, Curran S, Kent L, Richards S, Gould A, Virdee V, Huckett L, Sharp J, Batten C, Fernando S, Simanoff E, Thompson M, Zhao J, Sham P, Taylor E, Asherson P. 2001. Attention deficit hyperactivity disorder (ADHD) and the dopamine D4 receptor gene: Evidence of association but no linkage in a UK sample. Mol Psychiatry 6(4):440-444.

Mill J, Fisher N, Curran S, Richards S, Taylor E, Asherson P. 2003. Polymorphisms in the dopamine D4 receptor gene and attention-deficit hyperactivity disorder. Neuroreport 14(11):1463-1466.

Miller SA, Dykes DD, Polesky HF. 1988. A simple salting out procedure for extracting DNA from human nucleated cells. Nucleic Acids Res 16(3):1215.

Muglia P, Jain U, Macciardi F, Kennedy JL. 2000. Adult attention deficit hyperactivity disorder and the dopamine D4 receptor gene. Am J Med Genet 96(3):273-277.

Nikolaidis A, Gray JR. 2010. ADHD and the DRD4 exon III 7-repeat polymorphism: An international meta-analysis. Soc Cogn Affect Neurosci 5(2-3):188-193.

Polanczyk G, de Lima MS, Horta BL, Biederman J, Rohde LA. 2007. The worldwide prevalence of ADHD: A systematic review and metaregression analysis. Am J Psychiatry 164(6):942-948.

Purcell S, Cherny SS, Sham PC. 2003. Genetic power calculator: Design of linkage and association genetic mapping studies of complex traits. Bioinformatics 19(1):149-150.

Qian Q, Wang Y, Li J, Yang L, Wang B, Zhou R, Glatt SJ, Faraone SV. 2007. Evaluation of potential gene-gene interactions for attention deficit hyperactivity disorder in the Han Chinese population. Am J Med Genet Part B 144B(2):200-206.

Rasmussen ER, Neuman RJ, Heath AC, Levy F, Hay DA, Todd RD. 2004. Familial clustering of latent class and DSM-IV defined attention-deficit/ hyperactivity disorder (ADHD) subtypes. J Child Psychol Psychiatry 45:589-598.

Ribasés M, Ramos-Quiroga JA, Hervás A, Bosch R, Bielsa A, Gastaminza X, Artigas J, Rodriguez-Ben S, Estivill X, Casas M, Cormand B, Bayés M. 2009. Exploration of 19 serotoninergic candidate genes in adults and children with attention-deficit/hyperactivity disorder identifies association for 5HT2A, DDC and MAOB. Mol Psychiatry 14(1):77-85.

Roman T, Schmitz M, Polanczyk G, Eizirik M, Rohde LA, Hutz MH. 2001. Attention-deficit hyperactivity disorder: A study of association with both the dopamine transporter gene and the dopamine D4 receptor gene. Am J Med Genet 105(5):471-478.

Ronai Z, Guttman A, Keszler G, Sasvari-Szekely M. 2004. Capillary electrophoresis study on DNA-protein complex formation in the polymorphic 5' upstream region of the dopamine D4 receptor (DRD4) gene. Curr Med Chem 11(8):1023-1029.

Rowe DC, Stever C, Giedinghagen LN, Gard JM, Cleveland HH, Terris ST, Mohr JH, Sherman S, Abramowitz A, Waldman ID. 1998. Dopamine DRD4 receptor polymorphism and attention deficit hyperactivity disorder. Mol Psychiatry 3(5):419-426.

Sagvolden T, Johansen EB, Aase H, Russell VA. 2005. A dynamic developmental theory of attention-deficit/hyperactivity disorder (ADHD) predominantly hyperactive/impulsive and combined subtypes. Behav Brain Sci 28(3):397-419.

Sanchez-Mora C, Ribases M, Ramos-Quiroga JA, Casas M, Bosch R, Boreatti-Hummer A, Heine M, Jacob CP, Lesch KP, Fasmer OB, Knappskog PM, Kooij JJ, Kan C, Buitelaar JK, Mick E, Asherson P,
Faraone SV, Franke B, Johansson S, Haavik J, Reif A, Bayes M, Cormand B. 2010. Meta-analysis of brain-derived neurotrophic factor p.Val66Met in adult ADHD in four European populations. Am J Med Genet Part B $153 \mathrm{~B}(2): 512-523$.

Seaman MI, Fisher JB, Chang F, Kidd KK. 1999. Tandem duplication polymorphism upstream of the dopamine D4 receptor gene (DRD4). Am J Med Genet 88(6):705-709.

Shaw P, Gornick M, Lerch J, Addington A, Seal J, Greenstein D, Sharp W, Evans A, Giedd JN, Castellanos FX, Rapoport JL. 2007. Polymorphisms of the dopamine D4 receptor, clinical outcome, and cortical structure in attentiondeficit/hyperactivity disorder. Arch Gen Psychiatry 64(8):921-931.

Smith TF. 2010. Meta-analysis of the heterogeneity in association of DRD4 7-repeat allele and AD/HD: Stronger association with AD/HD combined type. Am J Med Genet Part B 153B(6):1189-1199.

Smith KM, Daly M, Fischer M, Yiannoutsos CT, Bauer L, Barkley R, Navia BA. 2003. Association of the dopamine beta hydroxylase gene with attention deficit hyperactivity disorder: Genetic analysis of the Milwaukee longitudinal study. Am J Med Genet Part B 119B(1):77-85.

Sobanski E, Bruggemann D, Alm B, Kern S, Philipsen A, Schmalzried H, Hesslinger B, Waschkowski H, Rietschel M. 2008. Subtype differences in adults with attention-deficit/hyperactivity disorder (ADHD) with regard to ADHD-symptoms, psychiatric comorbidity and psychosocial adjustment. Eur Psychiatry 23:142-149.

Sonuga-Barke EJ, Lasky-Su J, Neale BM, Oades R, Chen W, Franke B, Buitelaar J, Banaschewski T, Ebstein R, Gill M, Anney R, Miranda A, Mulas F, Roeyers H, Rothenberger A, Sergeant J, Steinhausen HC, Thompson M, Asherson P, Faraone SV. 2008. Does parental expressed emotion moderate genetic effects in $\mathrm{ADHD}$ ? An exploration using a genome wide association scan. Am J Med Genet Part B 147B(8):1359-1368.

Stephens M, Smith NJ, Donnelly P. 2001. A new statistical method for haplotype reconstruction from population data. Am J Hum Genet 68(4):978-989.

Tahir E, Yazgan Y, Cirakoglu B, Ozbay F, Waldman I, Asherson PJ. 2000. Association and linkage of DRD4 and DRD5 with attention deficit hyperactivity disorder (ADHD) in a sample of Turkish children. Mol Psychiatry 5(4):396-404.

Terwilliger J, Ott J. 1994. Handbook of human genetic linkage. Baltimore: Johns Hopkins University Press. pp 188-193.

Todd RD, Neuman RJ, Lobos EA, Jong YJ, Reich W, Heath AC. 2001. Lack of association of dopamine D4 receptor gene polymorphisms with ADHD subtypes in a population sample of twins. Am J Med Genet 105(5):432-438.

Van Tol HH, Wu CM, Guan HC, Ohara K, Bunzow JR, Civelli O, Kennedy J, Seeman P, Niznik HB, Jovanovic V. 1992. Multiple dopamine D4 receptor variants in the human population. Nature 358(6382):149-152.

Waldman ID, Rowe DC, Abramowitz A, Kozel ST, Mohr JH, Sherman SL, Cleveland HH, Sanders ML, Gard JM, Stever C. 1998. Association and linkage of the dopamine transporter gene and attention-deficit hyperactivity disorder in children: Heterogeneity owing to diagnostic subtype and severity. Am J Hum Genet 63(6):1767-1776.

Wang E, Ding YC, Flodman P, Kidd JR, Kidd KK, Grady DL, Ryder OA, Spence MA, Swanson JM, Moyzis RK. 2004. The genetic architecture of selection at the human dopamine receptor D4 (DRD4) gene locus. Am J Hum Genet 74(5):931-944.

Wohl M, Purper-Ouakil D, Mouren MC, Ades J, Gorwood P. 2005. Metaanalysis of candidate genes in attention-deficit hyperactivity disorder. Encephale 31(4Pt 1): 437-447.

Zintzaras E, Hadjigeorgiou GM. 2004. Association of paraoxonase 1 gene polymorphisms with risk of Parkinson's disease: A meta-analysis. J Hum Genet 49(9):474-481. 